\title{
Description of Alpheus cedrici sp. $n$., a strikingly coloured snapping shrimp (Crustacea, Decapoda, Alpheidae) from Ascension Island, central Atlantic Ocean
}

\author{
Arthur Anker ${ }^{1, \dagger}$, Sammy De Grave ${ }^{2, \ddagger}$ \\ I Instituto de Ciências do Mar (Labomar), Universidade Federal do Ceará (UFC), Fortaleza, Ceará, Brazil \\ 2 Oxford University Museum of Natural History, Oxford, United Kingdom \\ † urn:lsid:zoobank.org:author:B03ACF5D-1F1B-4653-9A7F-781804A2ABAB \\ ¥urn:lsid:zoobank.org:author:D009C42B-FB1F-4473-B6D4-D6C8389D0F74 \\ Corresponding author: Sammy De Grave (sammy.degrave@oum.ox.ac.uk)
}

Academic editor: Niel Bruce | Received 12 March 2012 | Accepted 3 April 2012 | Published 19 April 2012

urn:lsid:zoobank.org:pub:7861E107-FB5E-48CE-9AA8-23CAE43C86BD

Citation: Anker A, De Grave S (2012) Description of Alpheus cedrici sp. n., a strikingly coloured snapping shrimp (Crustacea, Decapoda, Alpheidae) from Ascension Island, central Atlantic Ocean. ZooKeys 183: 1-15. doi: $10.3897 /$ zookeys.183.3073

\begin{abstract}
Alpheus cedrici sp. n. is described based on two specimens collected under rocks while scuba diving off the coast of Ascension Island, central Atlantic Ocean. The new species belongs to the Alpheus macrocheles (Hailstone, 1835) species complex and appears to be most closely related to the eastern-central Atlantic A. macrocheles, the western Atlantic A. amblyonyx Chace, 1972, and the eastern Pacific A. bellimanus Lockington, 1877 and $A$. rectus Kim \& Abele, 1988. However, it differs from all these species by a combination of morphological characters and by a diagnostic and striking colour pattern.
\end{abstract}

\section{Keywords}

Caridea, Alpheidae, new species, Alpheus, Ascension Island, Atlantic Ocean

\section{Introduction}

The current knowledge of the alpheid shrimp fauna of the isolated central Atlantic islands St. Helena and Ascension is mainly based on two accounts, Chace (1966) for St. Helena and Manning and Chace (1990) for Ascension. Chace (1966) reported only 
three alpheid species from St. Helena, viz. Alpheus macrocheles (Hailstone, 1835), Synalpheus fritzmuelleri Coutière, 1909, and Metalpheus paragracilis (Coutiere, 1897). Manning and Chace (1990) reported the same three alpheids from Ascension Island, and in addition Alpheus bouvieri A. Milne Edwards, 1878, A. crockeri (Armstrong, 1941) [with some doubts], A. dentipes Guérin, 1832, A. holthuisi Ribeiro, 1964, A. paracrinitus Miers, 1881, Automate dolichognatha De Man, 1888, Metalpheus rostratipes (Pocock, 1890), Parabetaeus hummelincki (Schmitt, 1936) [as Neoalpheopsis euryone (De Man, 1910)], Salmoneus setosus Manning \& Chace, 1990, and S. teres Manning \& Chace, 1990, resulting in a total of 13 species of Alpheidae known to occur in the Central Atlantic Ocean south of Equator. Most alpheid specimens reported in Chace (1966) and Manning and Chace (1990) were collected in intertidal and shallow subtidal habitats, in tide pools, under rocks, in crevices of rocks and conglomerates of coralline algae, or in buoy fouling.

In April 2008, while scuba diving in English Bay, Ascension Island, one of us (SDG) collected two strikingly coloured snapping shrimps, by flipping rocks at a depth range of 10-15 m. A closer examination of these specimens revealed that they belong to a hitherto unnamed species of Alpheus Fabricius, 1798. This species is herewith described as new. Type material is deposited in the collections of the Oxford University Museum of Natural History, Oxford, the United Kingdom (OUMNH. $\mathrm{ZC}$ ). Abbreviations used in the text: $\mathrm{cl}$, carapace length (measured from the tip of the rostrum to the posterior margin of the carapace); Mxp, maxilliped; P, pereiopod; CA, central Atlantic; EA, eastern Atlantic; WA, western Atlantic; EP eastern Pacific.

\section{Systematics}

\section{Family Alpheidae Rafinesque, 1815 \\ Genus Alpheus Fabricius, 1798}

\section{Alpheus cedrici sp. n.}

urn:Isid:zoobank.org:act:7887B4BB-52D9-4329-A8BC-F32D8FA19FFC http://species-id.net/wiki/Alpheus_cedrici

Figs $1-3$

Material examined. Holotype: male, cl $10.1 \mathrm{~mm}$, OUMNH.ZC.2008-11-0017, Ascension Island, west side of English Bay, 0753.675'S, 014 $22.999^{\prime} \mathrm{W}$, depth $10 \mathrm{~m}$, under rocks, leg S. \& H. De Grave, 16.04.2008. Paratype: ovigerous female, cl $11.8 \mathrm{~mm}$, OUMNH.ZC.2008-11-0018, Ascension Island, west side of English Bay, 0753.675'S $014^{\circ} 22.999^{\prime} W$, depth 15 m, under rocks, leg. S. \& H. De Grave, 17.04.2008.

Comparative material examined. Alpheus macrocheles (Hailstone, 1835): 1 male, cl 9.0 mm, OUMNH.ZC.2003-36-0002, Madeira, Canico, depth 20 m, leg. P. Wirtz, 02.11.2003. Alpheus amblyonyx Chace, 1972: 1 male, cl 5.6 mm, OUMNH.ZC.201103-0070, Panama, Isla Grande, in coral rubble, 1-1.5 m, leg. A. Anker, 09.12.2006. 


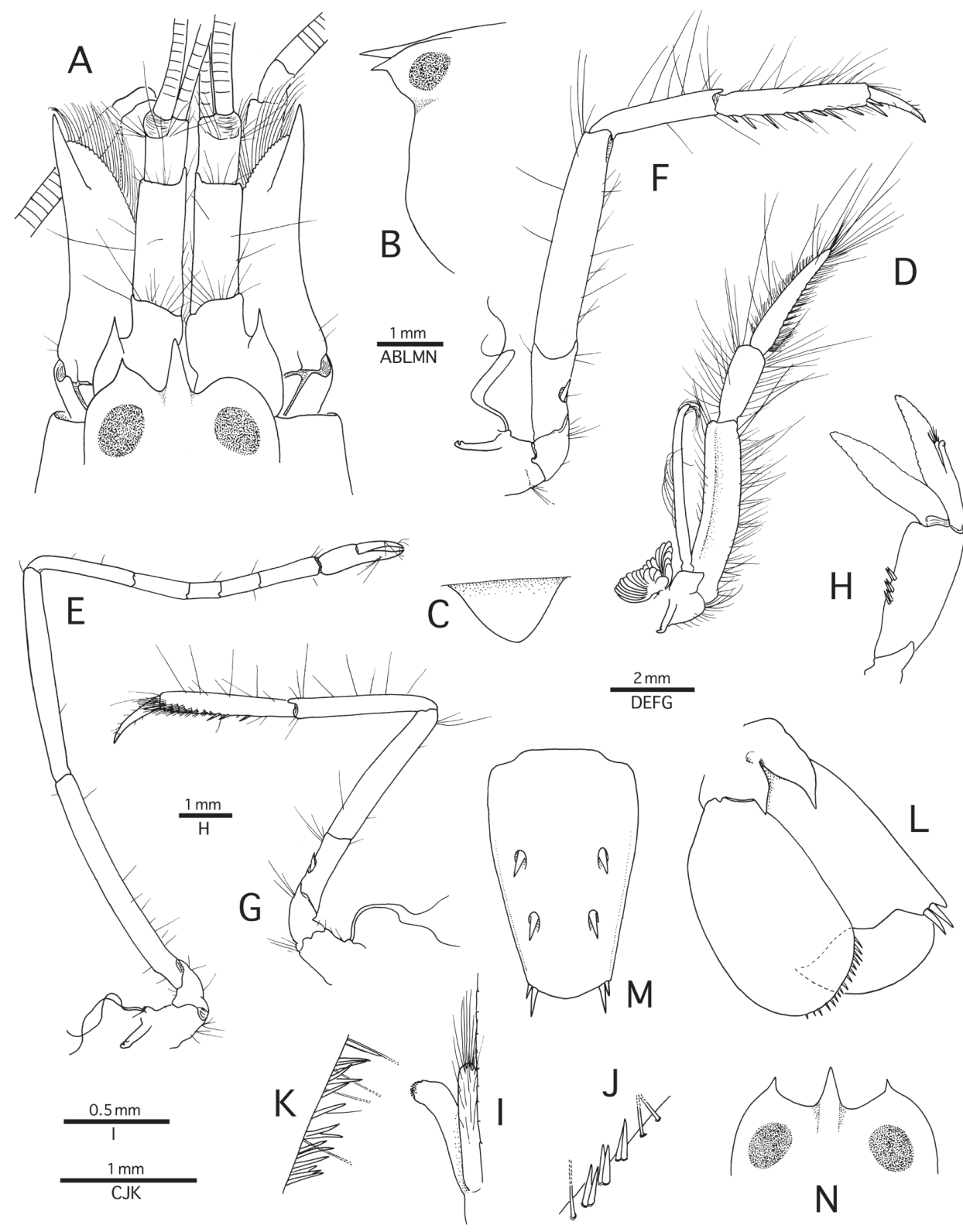

Figure I. Alpheus cedrici sp. n. A-M holotype, male from Ascension Island (OUMNH.ZC. 200811-0017); N paratype, female, same locality (OUMNH.ZC. 2008-11-0018). A frontal region, dorsal $\mathbf{B}$ anterior carapace, lateral $\mathbf{C}$ tooth of ventromesial carina of first article of antennular peduncle, lateral D third maxilliped, lateral E second pereiopod, lateral $\mathbf{F}$ third pereiopod, lateral $\mathbf{G}$ fifth pereiopod, lateral $\mathbf{H}$ second pleopod, lateral $\mathbf{I}$ same, appendix masculina and appendix interna, mesial $\mathbf{J}$ same, detail of spiniform setae on protopod, lateral $\mathbf{K}$ third pleopod, detail of spiniform setae on protopod, mesial $\mathbf{L}$ uropod, dorsal $\mathbf{M}$ telson, dorsal $\mathbf{N}$ anterior carapace, dorsal. 
Diagnosis. Frontal margin of carapace with rostrum slightly flattened dorsally, tapering distally, with acute tip, much longer than wide, reaching half-length of first article of antennular peduncle; rostral carina not distinct; orbital teeth in marginal position, small, acute distally, shorter than rostrum; margin between orbital teeth and rostrum broadly $\mathrm{V}$-shaped; rostro-orbital process present; pterygostomial angle rounded; antennular peduncle with stylocerite not reaching distal margin of first article, with acute tip; second article about 2.5 times as long as wide; antenna with basicerite terminating in sharp distoventral tooth; carpocerite slightly exceeding both scaphocerite and antennular peduncle; scaphocerite with well-developed blade, shallowly concave lateral margin and large, stout distolateral tooth, latter reaching far beyond distal margin of blade; male minor cheliped with ventromesial margin of merus ending in small, acute distomesial tooth, and with minute spiniform setae; palm strongly compressed, with sculpture on both lateral and mesial surfaces, consisting of low crests ending in sharp teeth distally; lateroventral surface with distinct, rounded shoulder; pollex shallowly excavated on cutting edge; dactylus somewhat flattened and twisted laterally, not conspicuously broadened, only slightly convex dorsally; male and female major chelipeds similar in shape and in proportions; ventromesial surface of ischium with small spiniform seta; ventromesial margin of merus straight, ending in stout, sharp distomesial tooth, and with small, widely spaced spiniform setae; palm somewhat compressed, with strong sculpture on lateral and mesial surfaces, consisting of low crests ending in sharp teeth distally; lateroventral surface with rounded, smooth, non-projecting shoulder adjacent to deep notch, latter continuing transversely to shallow groove on mesial surface; dorsal margin with subcylindrical elevation ending in large adhesive disk distally; distomesial surface with transversally deeply notched crest ending in sharp tooth; pollex shorter than dactylus, somewhat twisted and shallowly depressed laterally, cutting edge bluntly projecting laterally; dactylus flattened, twisted laterally, convex dorsally, bulbous distally, plunger reduced to broad, low tooth; second pereiopod with five-articulated carpus, ratio of articles approximately equal to $4: 2: 1: 1.5: 2$; third and fourth pereiopods similar; ischium armed with spiniform seta on ventrolateral surface; merus about five times as long as wide, without distoventral tooth; propodus with about eight spiniform setae along ventral margin and additional pair of spiniform setae close to propodo-dactylar articulation; dactylus about 0.4 length of propodus, simple, conical, faintly curved, with acute tip; pleopods with protopods furnished with spiniform setae on lateral margin, some inserted in pairs; male second pleopod with appendix masculina subequal in length to appendix interna, not reaching distal margin of endopod; uropodal exopod with sinuous diaeresis and small distolateral spiniform seta; uropodal endopod with row of small spiniform setae along distolateral margin; telson subrectangular, tapering posteriorly, about twice as long as wide at base; dorsal surface with two pairs of strong spiniform setae, first pair anterior to telson mid-length, second pair at about 0.7 telson length; posterior margin broadly convex, with two pairs of posterolateral spiniform setae, mesial about twice as long as lateral; anal tubercles well developed; gill-exopod formula typical for genus. 


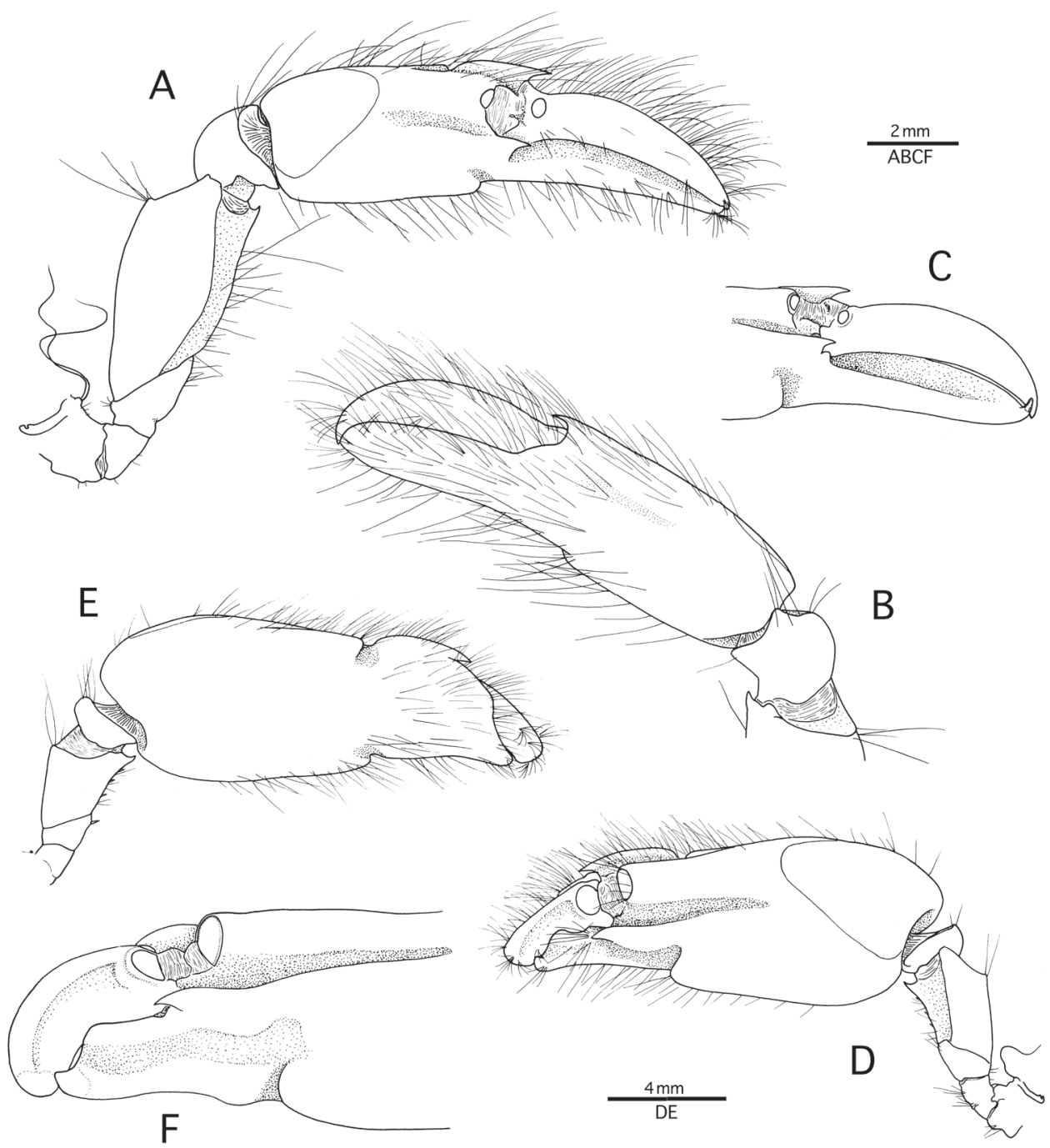

Figure 2. Alpheus cedrici sp. n. Holotype, male from Ascension Island (OUMNH.ZC. 2008-11-0017). A minor (right) cheliped, lateral $\mathbf{B}$ minor (right) chela and carpus, mesial $\mathbf{C}$ same, distal palm and fingers, lateral, setae omitted $\mathbf{D}$ major (left) cheliped, lateral $\mathbf{E}$ major (right) cheliped, mesial $\mathbf{F}$ same, distal palm and fingers, lateral, setae omitted.

Description. Body stout, laterally not compressed. Carapace glabrous; frontal margin with well-developed rostrum and orbital teeth; rostrum slightly flattened dorsally, tapering distally, with acute tip, much longer than wide; lateral margins without setae; tip reaching half-length of first article of antennular peduncle; rostral carina not distinct; orbital teeth in marginal position, relatively small, acute distally, shorter than rostrum (note: right orbital hood atypical, i.e. without tooth in male); margin between orbital teeth and rostrum broadly $\mathrm{V}$-shaped; orbital hoods moderately swollen, enclos- 
ing eyes from all sides (Fig. 1A, B); rostro-orbital process present. Pterygostomial angle rounded, not protruding anteriorly (Fig. 1B); cardiac notch deep. Abdominal somites with posteroventral margins broadly rounded, fifth slightly more angular; sixth somite without articulated flap, bluntly projecting posteriorly.

Eyes with well-developed corneas; anteromesial margin bluntly protruding. Ocellar beak projecting, acute, visible in lateral view. Epistomial sclerites not acutely projecting.

Antennule with moderately slender peduncle; stylocerite not reaching distal margin of first article, with acute tip; ventromesial carina with large, subtriangular tooth as illustrated (Fig. 1C); second article much longer than dorsally visible portion of first article, about 2.5 times as long as wide (Fig. 1A); lateral flagellum with groups of aesthetascs starting from $12^{\text {th }}$ article. Antenna with basicerite terminating in sharp distoventral tooth; carpocerite slightly exceeding both scaphocerite and antennular peduncle; scaphocerite with shallowly concave lateral margin and large, stout distolateral tooth, latter reaching far beyond distal margin of blade (Fig. 1A).

Mouthparts (not dissected) not specific in external view. Third maxilliped rather slender; coxa with lateral plate somewhat truncate distally; exopod long, overreaching distal margin of antepenultimate article; antepenultimate article somewhat flattened, ventral margin densely setose; penultimate article no more than three times as long as greatest width, distally slightly widening, very setose; ultimate article slender, tapering distally, with rows of serrulate setae and long, simple setae, tip unarmed (Fig. 1D).

Male minor cheliped with short, stout ischium; merus broad, subtriangular in cross-section; ventrolateral margin smooth; ventromesial margin straight, ending in small, acute distomesial tooth, and with four minute spiniform setae roughly equidistantly spaced along $0.6-0.7$ of merus margin, and with tips falling just short of margin (therefore invisible in lateral view); distodorsal angle blunt; carpus rounded, cup-shaped; chela strongly compressed, with palm sculptured distally; lateral surface with low crest starting at about mid-length of palm and ending in a sharp distolateral tooth; ventral margin with blunt, non-protruding shoulder and adjacent deep notch, latter continuing transversely forming a shallow depression on mesial surface; dorsal margin with subcylindrical elevation ending distally in small adhesive disk; distomesial surface with crest ending in stout sharp tooth; fingers as long as palm; pollex shallowly excavated on cutting edge; dactylus somewhat flattened and twisted laterally, slightly convex dorsally, proximally with small adhesive disk (Fig. 2A-C). Female minor cheliped unknown (missing in the paratype).

Male major cheliped with short, stout ischium, ventromesial surface with small spiniform seta; merus stout, short, broad, subtriangular in cross-section; ventrolateral margin smooth; ventromesial margin straight, ending in stout, sharp distomesial tooth, and with small, widely spaced spiniform setae; dorsal margin ending bluntly distally; carpus very short, cup-shaped; chela somewhat compressed; palm strongly sculptured; lateral surface with low crest starting at about 0.6 length of palm and ending in sharp distolateral tooth; ventral margin with rounded, smooth, non-projecting shoulder adjacent to deep notch, latter continuing transversely to shallow groove on mesial surface; dorsal margin with subcylindrical elevation ending in large adhesive disk dis- 

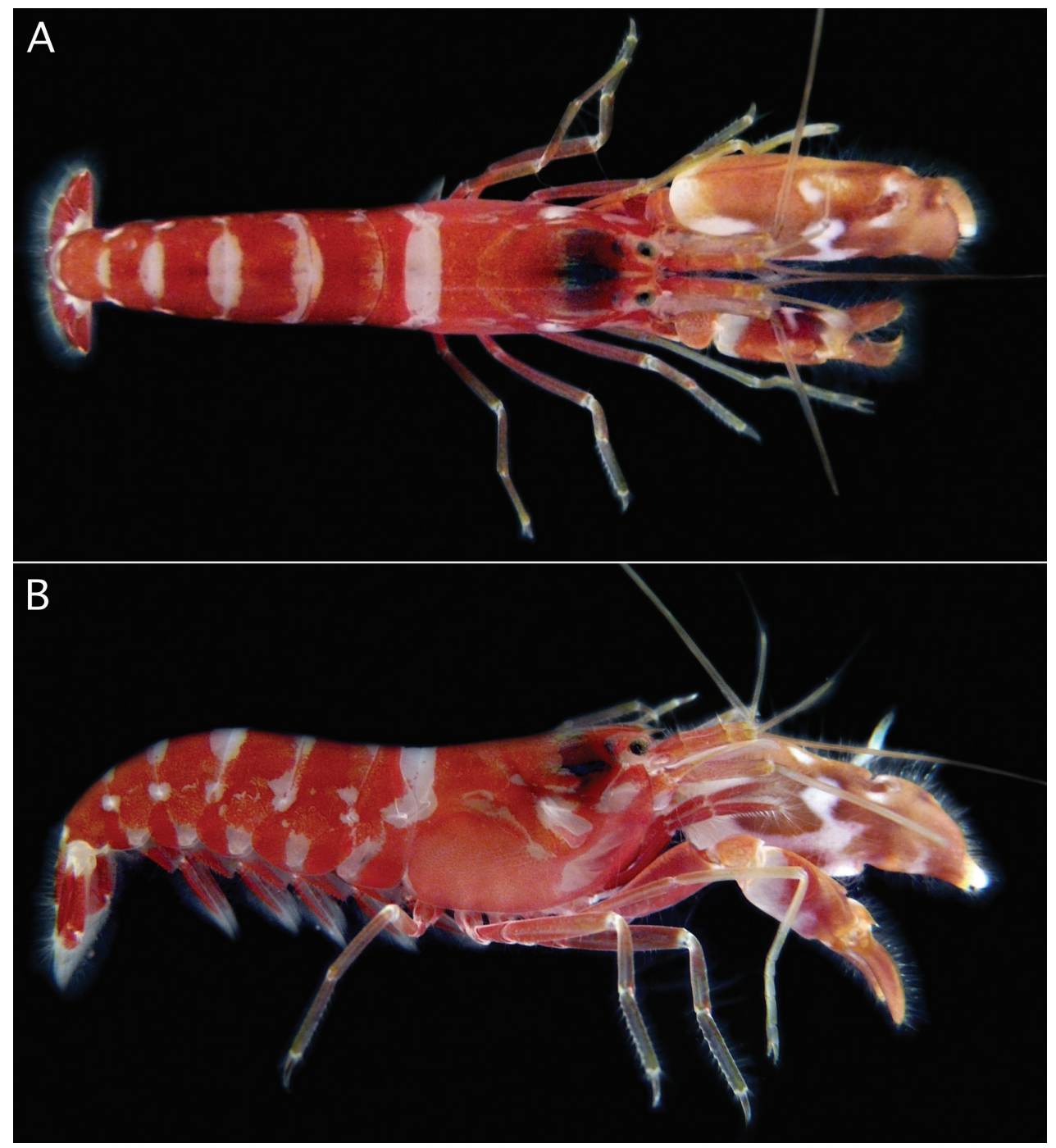

Figure 3. Alpheus cedrici sp. n. Holotype, male from Ascension Island (OUMNH.ZC. 2008-11-0017). A dorsal view B lateral view (photographs by S. De Grave).

tally; distomesial surface with transversally deeply notched crest ending in sharp tooth; pollex shorter than dactylus, somewhat twisted and shallowly depressed laterally, cutting edge bluntly projecting laterally; dactylus flattened, twisted laterally, convex dorsally, bulbous distally, plunger reduced to broad, low tooth (Fig. 2D-F). Female major cheliped generally similar in shape and proportions to male major cheliped.

Second pereiopod elongate, slender; ischium slightly longer than merus; carpus with five articles with ratio approximately equal to $4: 2: 1: 1.5: 2$; chela simple, fingers with scarce tufts of setae (Fig. 1E). Third and fourth pereiopods generally similar, 
moderately slender; third pereiopod with ischium armed with spiniform seta on ventrolateral surface; merus about five times as long as wide, without distoventral tooth; carpus more slender and about half as long as merus; propodus longer than carpus, with eight or so robust spiniform setae along ventral margin and one pair of longer spiniform setae adjacent to dactylus; dactylus about 0.4 length of propodus, simple, conical, faintly curved, with acute tip (Fig. 1F). Fifth pereiopod much more slender than third and fourth pereiopods; merus only slightly longer than carpus; ischium with spiniform seta; propodus with some spiniform setae along ventral margin and welldeveloped setal brush distolaterally (Fig. 1G).

Pleopods with protopods furnished with spiniform setae on lateral margin, some inserted in pairs (Fig. $1 \mathrm{H}, \mathrm{J}, \mathrm{K}$ ), first pleopod with small endopod furnished with setae, male second pleopod with appendix masculina subequal in length to appendix interna, not reaching distal margin of endopod, furnished with numerous stiff setae (Fig. 1I); female second pleopod with appendix interna only. Uropod with lateral lobe of protopod ending in large, acute tooth; diaeresis sinuous, with blunt tooth adjacent to one (occasionally two) stout distolateral spiniform seta(e); endopod with row of small spiniform setae along distolateral margin (Fig. 1L).

Telson subrectangular, tapering towards posterior margin, about twice as long as wide at base; lateral margins slightly convex; dorsal surface with two pairs of strong spiniform setae inserted at some distance from lateral margin, first pair anterior to telson mid-length, second pair at about 0.7 telson length; posterior margin about 0.6 length of anterior margin, broadly convex, with two pairs of posterolateral spiniform setae, mesial about twice as long as lateral (Fig. 1M); anal tubercles well developed.

Gill-exopod formula typical for Alpheus: five pleurobranchs (above P1-5), one arthrobranch (Mxp3), two lobe-shaped epipods (Mxp1-2), five mastigobranchs (Mxp3, $\mathrm{P} 1-4)$, five setobranchs (P1-5); three exopods (Mxp1-3).

Size. Alpheus cedrici sp. $\mathrm{n}$. is a medium-sized species of Alpheus, with $10.1 \mathrm{~mm} \mathrm{cl}$ for the male, and $11.8 \mathrm{~mm}$ for the ovigerous female.

Colour. Body ground colour bright red or red-orange; carapace mostly red with transverse white band along posterior margin and several colourless or whitish areas on flanks; abdomen mostly red with transverse, more or less oval-shaped, white bands, latter mainly dorsal and not extending to ventral margins of pleura, additional colourless or whitish patches present near ventral margin of each pleuron; major chelae orange-brown marbled with pale yellow on mesial side, and with a distinct, somewhat zigzag-shaped, transverse, white band on palm, extending ventrally and posteriorly; dactylus pale brown with white tip; minor chela similar to major chela, orange-brown with transverse white bands on palm, a broader, more diffuse distal band, and smaller, well-delimited, V-shaped, proximal band; second to fifth pereiopods pale reddish to yellowish, with white articulations; pleopods red; uropods and telson mostly red except for white uropodal protopods and most proximal portion of telson (Fig. 3).

Etymology. Named after our friend and colleague, Dr. Cedric d'Udekem d'Acoz, in recognition of his important contribution to the taxonomy of caridean shrimp and other decapods, particularly in the Atlantic Ocean. 
Habitat. Both specimens were collected by lifting large, shallowly buried rocks on a fine sandy substrate at depths between 10 and $15 \mathrm{~m}$, where the marginal boulder talus meets the sand. Other decapods obtained in the same habitat were the alpheids Automate cf. dolichognatha, Alpheus holthuisi, Metalpheus paragracilis, and the axiid Axiopsis cf. serratifrons (A. Milne-Edwards, 1873).

Type locality. English Bay, Ascension Island, central Atlantic Ocean.

Distribution. Central Atlantic Ocean: currently known only from the type locality.

Remarks. Alpheus cedrici sp. n. belongs to the monophyletic Alpheus macrocheles species group, which is comprised of about 30 species worldwide, all sharing a unique sculpture of the major chela (e.g. Coutière 1905; De Man 1911; Crosnier and Forest 1966; Banner 1953; Banner and Banner 1982; Kim and Abele 1988). Within the $A$. macrocheles species group, $A$. cedrici sp. n. belongs to the $A$. macrocheles species complex, characterised by the presence of acuminate orbital teeth on the frontal margin of the carapace; the major cheliped bearing a well-developed ventral notch and a dorsomesial notch or constriction; and the third and fourth pereiopods (P3-4) with unarmed meri and simple or minutely biunguiculate (not conspicuously biunguiculate) dactyli. The majority of species in the $A$. macrocheles complex are found in the Atlantic Ocean: A. macrocheles (EA, CA), A. platydactylus Coutière, 1897 (EA), A. amblyonyx Chace 1972 (WA), A. lentiginosus Anker \& Nizinski, 2011 (WA), A. puapeba Christoffersen, 1979 (WA), A. pouang Christoffersen, 1979 (WA), and $A$. cedrici sp. n. (CA). Two species are distributed in the eastern Pacific: $A$. bellimanus Lockington, 1877 (EP), and $A$. rectus Kim \& Abele, 1988 (EP). Finally, only one Indo-West Pacific species presents the above combination of characters: $A$. albatrossae (Banner, 1953). All these species are contrasted and compared with the new species below, in order of geographical proximity.

Alpheus macrocheles is a well-known, mostly shallow-water species (0-50 m, exceptionally to $185 \mathrm{~m}$ ), ranging in the eastern Atlantic from the British Isles and Mediterranean Sea south to Gabon, and extending to the Central Atlantic islands of Ascension and St. Helena (Holthuis 1951; Crosnier and Forest 1966; Chace 1966; Manning and Chace 1990). Alpheus cedrici sp. n. can be separated from A. macrocheles by the presence of a row of spiniform setae on the protopods of the pleopods (absent in $A$. macrocheles); the scaphocerite with a better developed blade (cf. Fig. 1A and Crosnier and Forest 1966, fig. 2a); and the male minor chela being more slender and with the dactylus less expanded and less arched dorsally (cf. Figs. 2A-C and Crosnier and Forest 1966, fig. 2c). The two species also differ in their colour patterns: the white bands and patches on the abdomen of $A$. cedrici sp. n. are contrasting with the mostly uniform deep-red to bright or pale orange abdomen of $A$. macrocheles (Fig. 4A, B). All records of $A$. macrocheles from the western Atlantic, e.g. records from Brazil (Ramos-Porto 1979; Guterres et al. 2005), have to be treated with some caution as they may refer to A. amblyonyx or other species of the $A$. macrocheles complex.

Alpheus platydactylus is a poorly known deep-water species $(50-600 \mathrm{~m})$ restricted to the northeastern Atlantic (Mediterranean Sea to the Azores and Cape Verde). Alpheus cedrici sp. n. can be easily distinguished from $A$. platydactylus by the much stout- 


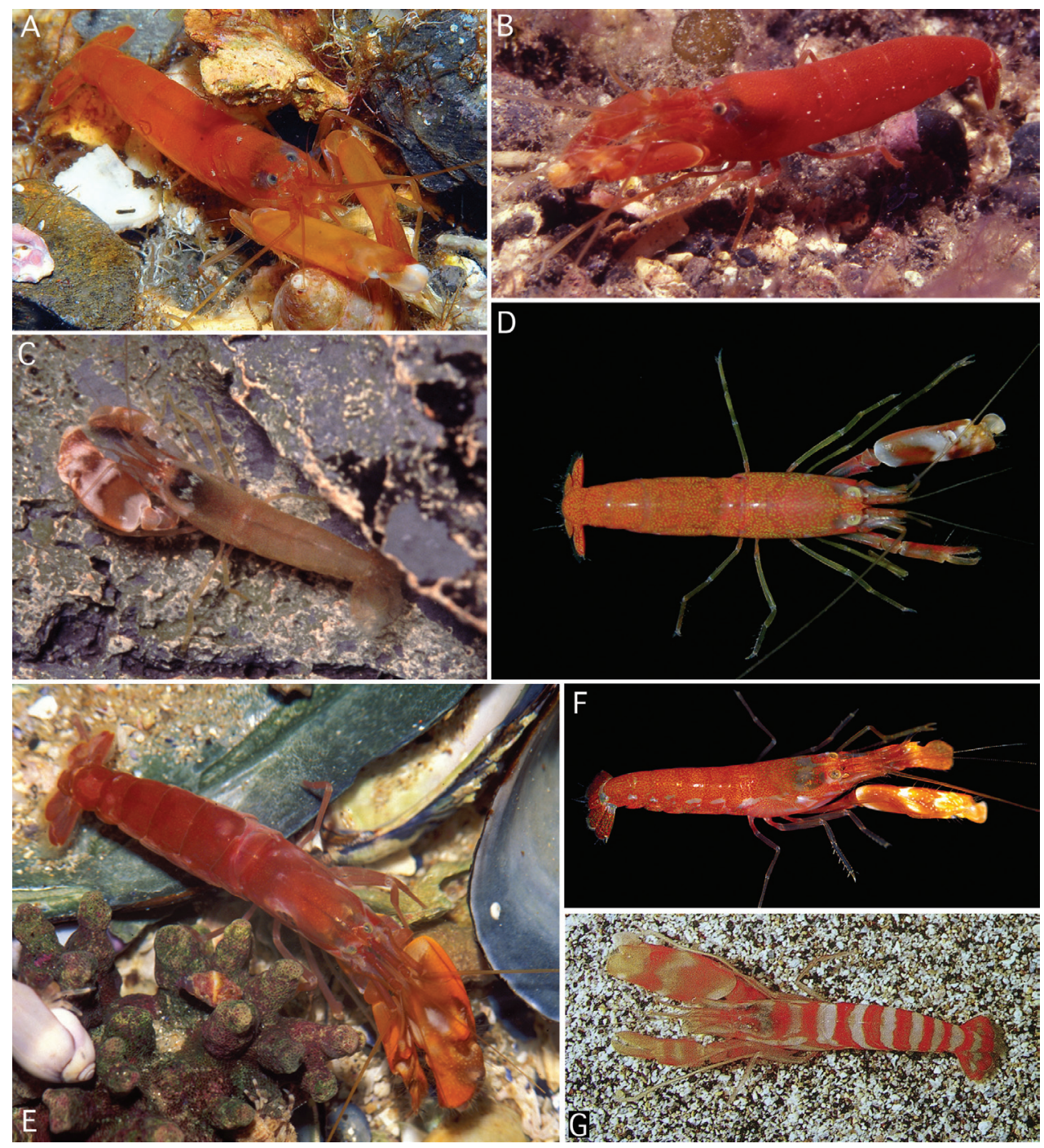

Figure 4. Colour patterns of some species of the Alpheus macrocheles (Hailstone, 1835) complex. A Alpheus macrocheles from Cadaques, Mediterranean coast of Spain B Alpheus macrocheles from Madeira C Alpheus amblyonyx Chace, 1972 from Guadeloupe D Alpheus amblyonyx from Isla Grande, Panama E Alpheus bellimanus Lockington, 1877 from Santa Barbara, California F Alpheus bellimanus from Galapagos G Alpheus sp. ? rectus Kim \& Abele, 1988, from the Gulf of California. Photographic credits: A, Josep Lluis Peralta; B, Peter Wirtz; C, Frédéric Fasquel; D, Arthur Anker; E, Gregory Jensen; F, Todd Zimmerman (courtesy of Cleveland Hickman); G, Alex Kerstitch (from Kerstitch 1988, courtesy of A. Kerstitch).

er, shorter antennular peduncles; the broader scaphocerite; the smooth ventral margin of the major chela palm (vs. rugose in A. platydactylus); the stouter minor chela, with the relatively shorter fingers; and the less slender second pereiopod (cf. Figs. 1, 2 and Crosnier and Forest 1966, fig. 2e-h). 
Alpheus amblyonyx, a species widespread in the western Atlantic from the Gulf of Mexico to Brazil (Chace 1972; Christoffersen 1998), is generally very similar to $A$. macrocheles. Chace (1972) separated $A$. amblyonyx from $A$. macrocheles mainly on the basis of four characters: (1) the more prominent rostrum; (2) the transverse notch on the mesiodorsal surface of the major chela palm broader and less sharply defined; (3) the major chela dactylus more strikingly bulbous distally; and (4) the minor chela dactylus without a high dorsal crest. With the exception of the last feature, A. cedricisp. n. can be separated from $A$. amblyonyx using the same criteria as from $A$. macrocheles (see above). The colour pattern of $A$. amblyonyx (Fig. 4C, D) is much more similar to the colour pattern of $A$. macrocheles (Fig. 4A, B) than to that of $A$. cedrici. sp. n. (Fig. 3).

Alpheus pouang and $A$. puapeba are two deep-water species presently known only from the southwestern Atlantic, off southern Brazil and Uruguay, at depth ranges of 120-268 m and 45-175 m, respectively (Christoffersen 1979, 1998). Alpheus cedrici sp. $\mathrm{n}$. can be distinguished from $A$. pouang by the anterior margin of the carapace between the rostrum and the orbital teeth being shallowly and broadly concave (vs. much more deeply incised in $A$. pouang), and the minor chela with a non-protruding ventral shoulder and a distinctly less flattened and dorsally arched dactylus (cf. Figs. 1-2 and Christoffersen 1979, figs. 14-15). The new species differs even more from A. puapeba, for example, by the much shorter antennular peduncles and the less elongate, more swollen major chela (cf. Figs. 1-2 and Christoffersen 1979, figs. 16-17). In addition, the pleopodal protopods of both $A$. pouang and $A$. puapeba are not armed with rows of spiniform setae (Christoffersen 1979, figs. 15r, 17d, 18f), as is the case of A. cedrici sp. n. (Fig. 1J).

Alpheus lentiginosus is another deep-water western Atlantic species presently known only from the northern Gulf of Mexico, at depths of 336-438 m (Anker and Nizinski 2011). Alpheus cedrici sp. n. can be separated from A. lentiginosus by the less expanded, dorsally non-arched dactylus of the minor chela; the less slender third to fifth pereiopods, with simple, conical dactyli (vs. with a minute accessory unguis on the flexor margin in A. lentiginosus); and the presence of spiniform setae on the pleopodal protopods (absent in A. lentiginosus) (cf. Figs 1-2 and Anker and Nizinski 2011, figs. 1-2). The colour patterns of $A$. cedrici sp. n. and A. lentiginosus are different as well (cf. Fig. 3 and Anker and Nizinski 2011, fig. 3).

The two eastern Pacific species of the A. macrocheles complex, A. bellimanus and A. rectus, are both morphologically very close to $A$. cedrici sp. n. Alpheus bellimanus is a relatively common species with a very wide depth range $(0-300 \mathrm{~m})$, and also with a wide geographic range, from California via Mexico, Panama and Galapagos to northern Chile (Kim and Abele 1988). Alpheus rectus is a much less common species from moderately deep-water $(55-73 \mathrm{~m})$; it is currently known only from the type locality in Panama and one locality in southern Baja California (Kim and Abele 1988). Alpheus cedrici sp. n. shares with $A$. bellimanus the presence of spiniform setae on the protopods of pleopods. The two species also have very similar frontal margins of the carapace, antennules and antennae, major chelipeds, and walking legs. However, A. cedrici sp. n. can be separated from $A$. bellimanus by the non-protruding ventral shoulder of the male minor chela (vs. protruding in A. bellimanus); the less expanded, dorsally non-arched 
dactylus of the male minor chela (vs. more expanded and dorsally strongly convex in A. bellimanus); and the anteriorly rounded tooth on the ventromesial carina of the first article of the antennular peduncle (vs. with a subacute tooth in $A$. bellimanus) (cf. Figs. 1-2 and Kim and Abele 1988, fig. 5). The colour pattern of A. bellimanus (Fig. 4E, F) resembles more the uniform colour patterns of $A$. macrocheles (Fig. 4A, B) and $A$. amblyonyx (Fig. 4C, D) than the distinctly banded colour pattern of A. cedrici sp. n. (Fig. 3).

The new species from Ascension also differs from $A$. rectus, for example, by the less rectangular general shape of the major chela, with the ventral shoulder of the palm broadly rounded, not protruding anteriorly (vs. bluntly projecting in $A$. rectus); and the anteriorly rounded tooth on the ventromesial carina of the first article of the antennular peduncle (vs. with a small point in $A$. rectus). The colour pattern of $A$. rectus remains unconfirmed. However, a colour photograph of a snapping shrimp erroneously identified as "Alpheus paracrinitus" in Kerstitch (1988) matches $A$. rectus, especially in the shape of the major and minor chelipeds. The colour pattern of this individual (Alpheus sp. ? rectus in Fig. 4G), although characterised by a conspicuous transversal orange-white banding, is different from that of $A$. cedrici sp. n., especially in the clearly banded carapace and the abdominal bands extending ventrally to the pleural margins (cf. Figs. 3, 4G).

All other species of the $A$. macrocheles group present in the western and eastern Atlantic and in the eastern Pacific differ more markedly from $A$. cedrici sp. n. (see Coutière 1910; Armstrong 1940, 1941; Holthuis 1951; Crosnier and Forest 1966; Chace 1972; Wicksten and Méndez 1981; Kim and Abele 1988; Wicksten and McClure 2003; Anker et al. 2008). The shape of the frontal margin of the carapace separates the new species from $A$. inca Wicksten \& Méndez, 1981, A. grahami Abele, 1975, A. cylindricus Kingsley, 1878, A. vanderbilti Boone, 1930, A. clamator Lockington, 1877, A. peasei (Armstrong, 1940), A. dentipes Guérin, 1832 and $A$. candei GuérinMéneville, 1855). The shape of the major cheliped separates the new species from $A$. crockeri (Armstrong, 1941), A. hortensis Wicksten \& McClure, 2003, A. grahami, A. cylindricus and $A$. vanderbilti. The shape of the minor cheliped separates the new species from A. hoonsooi Kim \& Abele, 1988, A. crockeri, A. hortensis, A. grahami, A. cylindricus and $A$. vanderbilti. The presence of a distinct distoventral tooth on the merus of the third and fourth pereiopod in A. hoonsooi, A. clamator, A. peasei and A. dentipes separates these species from $A$. cedrici sp. n. Finally, the strongly biunguiculate dactylus of the third to fifth pereiopods in A. clamator, A. peasei, A. dentipes and A. candei separates these species from $A$. cedrici sp. n.

Alpheus cedrici sp. n. can be separated from the Indo-West Pacific $A$. albatrossae by the presence of a distinct shoulder on the ventrolateral surface of the minor chela palm (absent in A. albatrossae); the stouter fingers of the minor chela; and the absence of a small unguis on the dorsal margin of the dactylus of the third to fifth pereiopods (present in A. albatrossae) (cf. Figs. 1, 2 and Banner, 1953, fig. 18). None of the other Indo-West Pacific species of the $A$. macrocheles group appears to be closely related to $A$. cedrici sp. n. (e.g. Coutière 1905; De Man 1911; Banner 1953; Kensley 1969; Banner and Banner 1982; Burukovsky 1990). 


\section{Acknowledgments}

Financial support for SDG's fieldwork in Ascension Island was provided by the Oxford University John Fell Fund, under a permit issued by the Ascension Conservation Department. H. De Grave assisted with and made fieldwork more enjoyable. AA is grateful to CAPES (Coordenação de Aperfeiçoamento de Pessoal de Nível Superior) for financial support in the form of a postdoctoral fellowship. Additional photographs used in this study were taken by Josep Lluis Peralta (Mataró, Spain), Gregory Jensen (University of Washington, USA), Peter Wirtz (Universidade do Algarve, Portugal), Todd Zimmerman / Cleveland P. Hickman (Lexington, USA), and the late Alex Kerstitch.

\section{References}

Abele LG (1975) The macruran decapod Crustacea of Malpelo Island. Smithsonian Contributions to Zoology 176: 69-85.

Anker A, Hurt C, Jara JA, Knowlton N (2008) Revision of the Alpheus cylindricus Kingsley, 1878 species complex (Crustacea: Decapoda: Alpheidae), with revalidation of $A$. vanderbilti Boone, 1930. Zootaxa 1943: 53-68.

Anker A, Nizinski M (2011) Description of a new deep-water species of Alpheus Fabricius, 1798 from the Gulf of Mexico (Crustacea, Decapoda, Alpheidae). Zootaxa 2925: 49-56.

Armstrong JC (1940) New species of Caridea from the Bermudas. American Museum Novitates 1096: 1-10.

Armstrong JC (1941) The Caridea and Stomatopoda of the second Templeton Crocker-American Museum expedition to the Pacific Ocean. American Museum Novitates 1137: 1-14.

Banner AH (1953) The Crangonidae, or snapping shrimp, of Hawaii. Pacific Science 7: 3-147. Banner DM, Banner AH (1982). The alpheid shrimp of Australia. Part III: The remaining alpheids, principally the genus Alpheus and the family Ogyrididae. Records of the Australian Museum 34: 1-357. doi: 10.3853/j.0067-1975.34.1982.434

Boone L (1930) Scientific results of the cruises of the yachts "Eagle" and "Ara", 1921-1928, William K. Vanderbilt, commanding. Crustacea: Anomura, Macrura, Schizopoda, Isopoda, Amphipoda, Mysidacea, Cirripedia, and Copepoda. Bulletin of the Vanderbilt Marine Museum 3: 1-221.

Burukovsky RN (1990) Shrimps from the Sala-y-Gomez and Nazca Ridges [in Russian]. Trudy Instituta Okeanologii Akademii Nauk SSSR 124: 187-217.

Chace FAJr (1966) Decapod crustaceans from St. Helena, South Atlantic. Proceedings of the United States National Museum 118: 622-662.

Chace FAJr (1972) The shrimps of the Smithsonian-Bredin Caribbean expeditions with a summary of the West Indian shallow-water species (Crustacea: Decapoda: Natantia). Smithsonian Contributions to Zoology 98: 1-179.

Christoffersen ML (1979) Campagne de la Calypso au large des côtes Atlantiques de l'Amerique du Sud (1961-1962). I. Decapod Crustacea: Alpheoida. Annales de l'Institut Océanographique 55(Suppl.): 297-377. 
Christoffersen ML (1998) Malacostraca. Eucarida. Caridea, Crangonoidea and Alpheoidea (except Glyphocrangonidae and Crangonidae). In: Young PS (Ed) Catalogue of Crustacea of Brazil. Museu Nacional, Rio de Janeiro, 351-372.

Coutière H (1897) Note sur quelques Alphées nouveaux. Bulletin du Muséum d'Histoire Naturelle, serie 3 7: 303-306.

Coutière H (1905) Les Alpheidae. In: Gardiner JS The Fauna and Geography of the Maldive and Laccadive Archipelagoes. Being the account of the work carried on and of the Collections made by an Expedition during the years 1899 and 1900. University Press, Cambridge, 852-921, pls. 70-87.

Coutière H (1909) The American species of snapping shrimps of the genus Synalpheus. Proceedings of the United States National Museum 36: 1-93. doi: 10.5479/si.00963801.36-1659.1

Coutière H (1910) The snapping shrimps (Alpheidae) of the Dry Tortugas, Florida. Proceedings of the United States National Museum 37: 485-487. doi: 10.5479/si.00963801.371716.485

Crosnier A, Forest J (1966) Résultats Scientifiques des Campagnes de la "Calypso". Fascicule VII. Campagne de la Calypso dans la Golfe de Guinée et aux Iles Principe, São Tomé et Annobon (1956), et campagne aux Iles du Cap Vert (1959) (suite). 19. Crustacés décapodes: Alpheidae. Annales de l'Institut Océanographique 44: 199-314.

Fabricius JC (1798) Supplementum Entomologiae Systematicae. Proft et Storch, Hafniae, 572 pp.

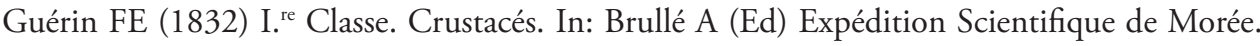
Section des Sciences Physiques. Tome III. - 1ère Partie. Zoologie. Deuxième Section. Des animaux articulés. Paris, 30-50, Plate 27.

Guérin-Méneville FE (1855-1856) Animales articulados con piés articulados. In: de la Sagra R (Ed) Historia fisica politica y natural de la isla de Cuba. Segunda Parte. Historia Natural. Tomo VII (Crustaceos, Aragnides é Insectos) [1856]; Tomo VIII (Atlas de Zoologia) [1855]. Paris, i-xxxii, 1-371, pls. 1-20.

Guterres LFR, Melo GAS, Castro-Guterres P (2005) Novos registros de ocorrência de Alpheus macrocheles (Crustacea, Caridea, Alpheidae) na costa do Brasil. Biociências 13: 231-233.

Hailstone S (1835) The species of crustaceous animals discovered and described by Mr. Hailstone, and illustrated and annotated upon by Mr. Westwood. The Magazine of Natural History and Journal of Zoology, Botany, Mineralogy, Geology, and Meteorology 8: 394-395.

Holthuis LB (1951) The caridean Crustacea of tropical West Africa. Atlantide Report 2: 1-187.

Kensley B (1969) Decapod Crustacea from the south-west Indian Ocean. Annals of the South African Museum 52: 149-181.

Kerstitch A (1988) Sea of Cortez marine invertebrates. A guide for the Pacific coast, Mexico to Ecuador. Sea Challengers, Monterey, 113 pp.

Kim W, Abele LG (1988) The snapping shrimp genus Alpheus from the Eastern Pacific (Decapoda: Caridea: Alpheidae). Smithsonian Contributions to Zoology 454: 1-119. doi: $10.5479 /$ si.00810282.454

Kingsley JS (1878) A synopsis of the North American species of the genus Alpheus. Bulletin of the United States Geological and Geographical Survey 4: 189-199.

Lockington WN (1877) Remarks on the Crustacea of the Pacific Coast, with descriptions of some new species. Proceedings of the California Academy of Sciences 7 [for 1876]: 28-36. 
Man JG de (1888) Bericht über die von Herrn Dr. J. Brock im indischen Archipel gesammelten Decapoden und Stomatopoden. Archiv für Naturgeschichte 53: 289-600.

Man JG de (1910) Diagnoses of new species of macrurous decapod Crustacea from the "SibogaExpedition”. Tijdschrift der Nederlandse Dierkundige Vereniging, series 2 11: 287-319.

Man JG de (1911) The Decapoda of the Siboga Expedition. Part II. Family Alpheidae. Siboga Expeditie 39a1: 133-465.

Manning RB, Chace FAJr (1990) Decapod and stomatopod Crustacea from Ascension Island, South Atlantic Ocean. Smithsonian Contributions to Zoology 503: 1-91. doi: 10.5479/ si.00810282.503

Miers EJ (1881) On a collection of Crustacea made by Baron Hermann-Maltzan at Goree island, Senegambia. The Annals and Magazine of Natural History, series 5 8: 204-220, 259.

Milne-Edwards A (1873) Description de quelques crustacés nouveaux ou peu connus provenant du Musée de M. C. Godeffroy. Journal des Museum Godeffroy 1: 77-88.

Milne-Edwards A (1878) Description de quelques espèces nouvelles de Crustacés provenant du voyage aux îles du Cap-Vert de MM. Bouvier et de Cessac. Bulletin de la Société Philomathique de Paris, serie 7 2: 225-232.

Pocock RI (1890) Crustacea. The Journal of the Linnean Society. Zoology 20: 506-526.

Rafinesque CS (1815) Analyse de la Nature ou Tableau de l'Univers et des corps organisés. Palerme, $224 \mathrm{pp}$.

Ramos-Porto M (1979) Ocorrência de Alpheus macrocheles (Hailstone) (Crustacea: Decapoda: Alpheidae) no Norte e Nordeste do Brasil. Trabalhos do Instituto Oceanográfico da Universidade Federal do Pernambuco 14: 117-130.

Ribeiro A (1964) Sobre uma espécie nova de Alpheus Fabricius, 1798 do Arquipélago de Cabo Verde, Alpheus holthuisi n. sp. Notas Mimeografadas do Centro de Biologia Piscatória, Lisboa 42: 1-14.

Schmitt WL (1936) Zoologische Ergebnisse einer Reise nach Bonaire, Curaçao und Aruba im Jahre 1930. No. 16. Macruran and anomuran Crustacea from Bonaire, Curaçao und Aruba. Zoologische Jahrbücher 67: 363-378.

Wicksten MK, McClure MR (2003) A new species of Alpheus (Decapoda: Caridea: Alpheidae) from the Gulf of Mexico. Crustacean Research 32: 26-31.

Wicksten MK, Méndez MG (1981) Alpheus inca: a new snapping shrimp (Caridea: Alpheidae) from western South America. Journal of Crustacean Biology 1: 137-142. doi: $10.2307 / 1548211$ 
